\title{
Evaluation of skin sensitivity in individuals presented with temporomandibular disorder
}

\author{
Giovanna Siqueira Faustino da Silva ${ }^{1}$ \\ https://orcid.org/0000-0003-4473-0972 \\ Clarissa Evelyn Bandeira Paulino ${ }^{1}$ \\ https://orcid.org/0000-0002-9028-649X \\ Maurício Kosminsky² \\ https://orcid.org/0000-0003-3111-7837 \\ Luciana Moraes Studart-Pereira ${ }^{1}$ \\ https://orcid.org/0000-0003-0030-1463
}

Universidade Federal de Pernambuco, Recife, Pernambuco, Brasil.

${ }^{2}$ Faculdade de Odontologia de Pernambuco, Recife, Pernambuco, Brasil.

Conflict of interests: Nonexistent

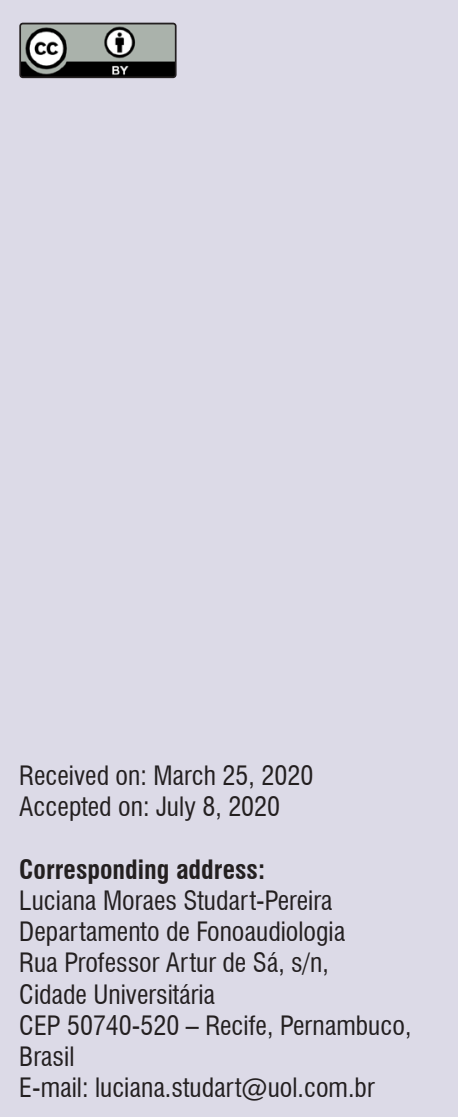

\section{ABSTRACT}

Purpose: to identify the occurrence of a difference in skin sensitivity between analogous points on the face in individuals with temporomandibular disorder.

Methods: a total of 60 individuals of both genders, aged 18 to 73 years, participated in the study. People classified with TMD signs and symptoms with the Fonseca Anamnestic Questionnaire were included. The skin sensitivity was evaluated with a Semmes-Weinstein esthesiometer. Sensitivity change was defined in this study as the occurrence of a difference between analogous points on both hemifaces. The localization of the points followed the regional block anatomical description and was confirmed with a neuromuscular electrostimulation device. The collected data were analyzed statistically with a $5 \%$ significance level.

Results: the occurrence of a difference in sensitivity between the analogous points had a significant association with age group and severity of TMD. However, no association was perceived between sensitivity change and gender.

Conclusion: in the population studied, the more severe the temporomandibular disorder, the greater the skin sensitivity change on the face. Also, the older the person, the higher the number of analogous points with a difference in sensitivity.

Keywords: Face; Sensory Thresholds; Perception; Facial Pain 


\section{INTRODUCTION}

The stomatognathic system (SS) is richly characterized by proprioceptors that make it particularly sensitive and capable of efficiently controlling the motor function of the system. The stomatognathic proprioceptive mechanisms are decisive factors in the control of the stomatognathic function, driving the central nervous system to reach a functioning level adequate to the physiological purpose ${ }^{1}$.

Sensitivity is the conscious interpretation of environmental sensory stimuli. Losing it or having it changed can cause important functional loss. In this regard, measuring it is extremely important ${ }^{2}$.

The main sensitivity points ramify into objective surface sensitivity (involving tactile, pain, and thermal sensitivity) and objective deep sensitivity (encompassing vibratory, paresthetic, nerve trunk, visceral, segmental, active and passive movements, resistance, weight, and strength sensitivity) ${ }^{3}$.

Surface sensitivity (exteroceptive) provides information on the external stimuli of the skin receptors. Threshold tests establish the minimum stimulus value that can be perceived by the person, associated with the four classic skin functions: pain, heat, cold, soft touch/deep pressure ${ }^{2}$.

Knowing how the nociceptive impulses are produced and how they are processed by the central nervous system is of great importance to understand the functioning of the stomatognathic system in patients with temporomandibular disorders (TMD) and chronic orofacial pain. Although such pathology has already been widely studied, the definition of its etiology and mechanism is still controversial, given the current possibilities of treatment ${ }^{4}$.

TMD encompasses a series of changes, either painful or not, in the region of the temporomandibular joint (TMJ), masticatory musculature, or both structures. The pains resulting from this pathology - usually located in the region of the temporal muscle or in the joint itself - can produce, besides limited articulatory movements and impaired orofacial function performance ${ }^{5}$, complaints related to anxiety and headache ${ }^{6}$. It is an either acute or chronic affection of multifactorial origin. When the pain becomes chronic, it is often associated with emotional, mood, and depression disorders, and central mechanisms that maintain the pain, such as the neuroplasticity process that changes the function of the central neurons either temporarily or permanently ${ }^{7,8}$. These changes are responsible for making the pain chronic, for transforming an acute pain in a chronic and persistent one ${ }^{9}$.

TMD-related chronic pain is considered the third most prevalent chronic pain condition. It can sharply impair these patients' quality of life $^{10}$, lingering even after the lesion was remitted, due to central sensitization. It is usually nonresponsive to traditional therapy and requires multidisciplinary treatment ${ }^{11,12}$.

Various stimuli are necessary to evaluate the integrity of the afferent fibers, to understand the mechanisms involved in different painful conditions affecting the orofacial region. In this sense, quantitative sensory tests can be useful as instruments to identify these neural processes, as they enable somatosensory changes to be verified in pathological conditions with chronic pain. The type of afferent impulse, responsible for transmitting tactile, thermal, and pain stimuli, is related to a type of fiber. The tactile mechanical stimulus (to be tested in this study) is an excitation transmitted by rapid A-beta fibers, whose threshold can be effectively tested with monofilaments ${ }^{9}$.

By the end of the $19^{\text {th }}$ century, Von Frey developed an instrument made of horsehair, focused on studying normal physiology - at that time, only soft touch thresholds were measured. Semmes and Weinstein developed in 1962 a broad set of nylon monofilaments that replaced Von Frey's ${ }^{2}$. Currently known as esthesiometer, this instrument has six colored nylon monofilaments, each color representing a sensitivity threshold. This set of filaments is available in the SemmesWeinstein manufactured by Sorri ${ }^{13}$.

Studies highlight the esthesiometer's contribution to the measurement of sensitivity thresholds in regions that have already undergone some type of surgical intervention ${ }^{14}$. Although this instrument was meant for plantar and palmar evaluation, its use in the orofacial region has already been described in speech-languagehearing studies. It has been used to evaluate patients before and after orthognathic surgery to investigate the involvement of lower and midfacial skin sensitivity changes in oral function performance ${ }^{15}$. Monofilaments have also been reported in its use to measure sensitivity in patients with different pathological conditions, including temporomandibular disorder ${ }^{16}$.

Therefore, conducting this research has been justified by the contributions brought by the knowledge of skin sensitivity thresholds in patients with TMD to the studies related to face proprioception and SS.

The investigation of peripheral repercussions of central sensitization, present in patients with chronic 
pain, interests not only the field of Dentistry but also that of Speech-Language Therapy - whose intervention procedures in this group of patients are based on therapy methods that involve peripheral stimuli. Hence, understanding such a mechanism is an essential step to decision-making.

This investigation aimed to identify the occurrence of different skin sensitivity between analogous points of the face in people presented with temporomandibular disorder.

\section{METHODS}

This research was approved by the ethics committee of the Universidade Federal de Pernambuco, Brazil, under evaluation report no. 2.514.702.

This was an analytical, observational, cross-sectional study whose variables were gender, age group, and severity of pain. It was conducted in the facilities of the Dentistry and Speech-Language-Hearing programs of two public universities of Pernambuco, Brazil. A total of 60 individuals of both genders, aged 18 to 73 years, participated in the study. They were patients attending an orofacial pain reference center, as well as professors, students, and employees from these institutions.

The people included in the study were those classified with signs and symptoms of TMD with the Fonseca Anamnestic Questionnaire (DMF) ${ }^{17}$, with or without complaint of orofacial pain. The exclusion criteria considered individuals who had been submitted to face surgeries and/or trauma; with a history of facial paralysis; with syndromes or changes related to the face structures; with a disability; with neurological or psychiatric problems that hindered communication; and people undergoing dental and/or speechlanguage-hearing treatment for TMD or orofacial pain at the time of the collection.

The participants were categorized as mild, moderate, or severe TMD, according to DMF, which is meant to evaluate the presence and classify the degree of severity of temporomandibular disorder ${ }^{17}$.

After the DMF was administered to the volunteers who initially complained of orofacial pain, they were asked about the beginning of the pain symptoms. It was then verified that all the participants with severe TMD reported having pain for over three months, which is considered chronic $^{18}$. Nevertheless, this parameter was not analyzed in the present study.

Data were collected in individual evaluations. Initially, the participant answered a questionnaire for identification, which also had questions about facial pain complaints. Then, the subjects were evaluated following the methodological steps shown in Figure 1.

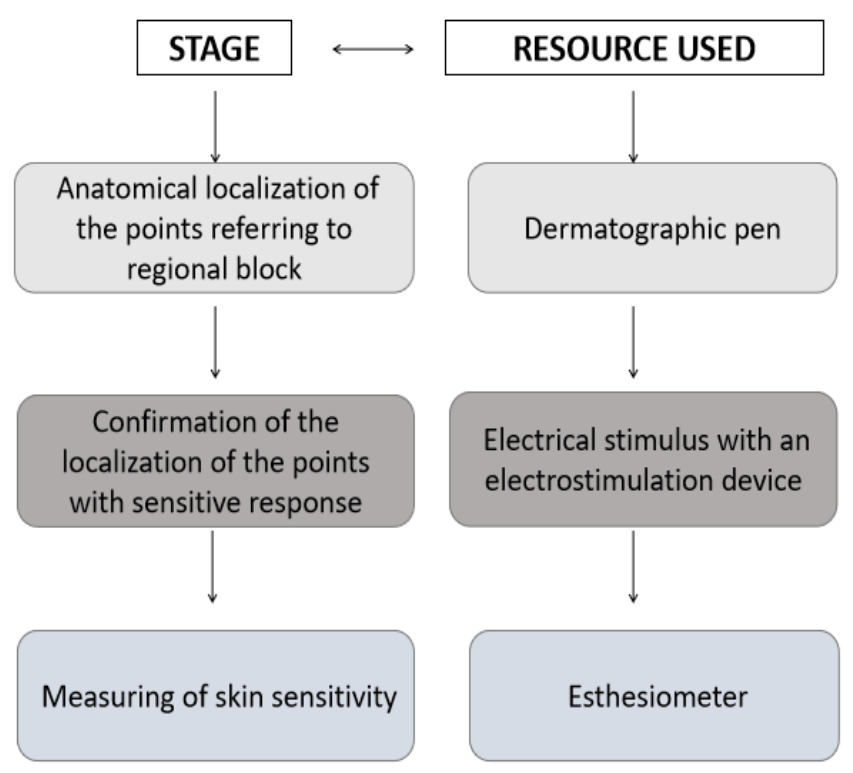

Source: The authors

Figure 1. Data collection flowchart

Figure 2 indicates the anatomical localization of the trigeminal and facial nerves regional block points, according to the Atlas de Técnicas de Bloqueios Regionais da Sociedade Brasileira de Anestesiologia (Atlases of Regional Anesthesia Techniques from the Brazilian Anesthesiology Society) ${ }^{19}$.

The points on the face were marked with a dermatographic pencil. To assure the right localization, the points were confirmed with a Neurodyn II - Ibramed neuromuscular electrostimulation device, used on the face with electrostimulation pens. The decision to use this complementary procedure was due to the anatomical variations from person to person, while the regions that were going to be tested with the esthesiometer needed to be precisely identified. Studies show variations in the ramifications of the trigeminal nerve ${ }^{20}$ and facial nerve ${ }^{21}$; accordingly, the regional block points can be more medially or laterally located.

A low-frequency sensory current with minimum stimulation time and intensity was applied to pick up a response in that region. The volunteer was instructed to report a slight tingling or any other sensation. It should be highlighted that the stimulus applied was not enough to generate muscle contractions, neural accommodation, or muscular tetany. In the cases whose electrical confirmation did not coincide with the traditional anatomical markings, adjacent regions were tried until the participant reported a response to the stimulus. 

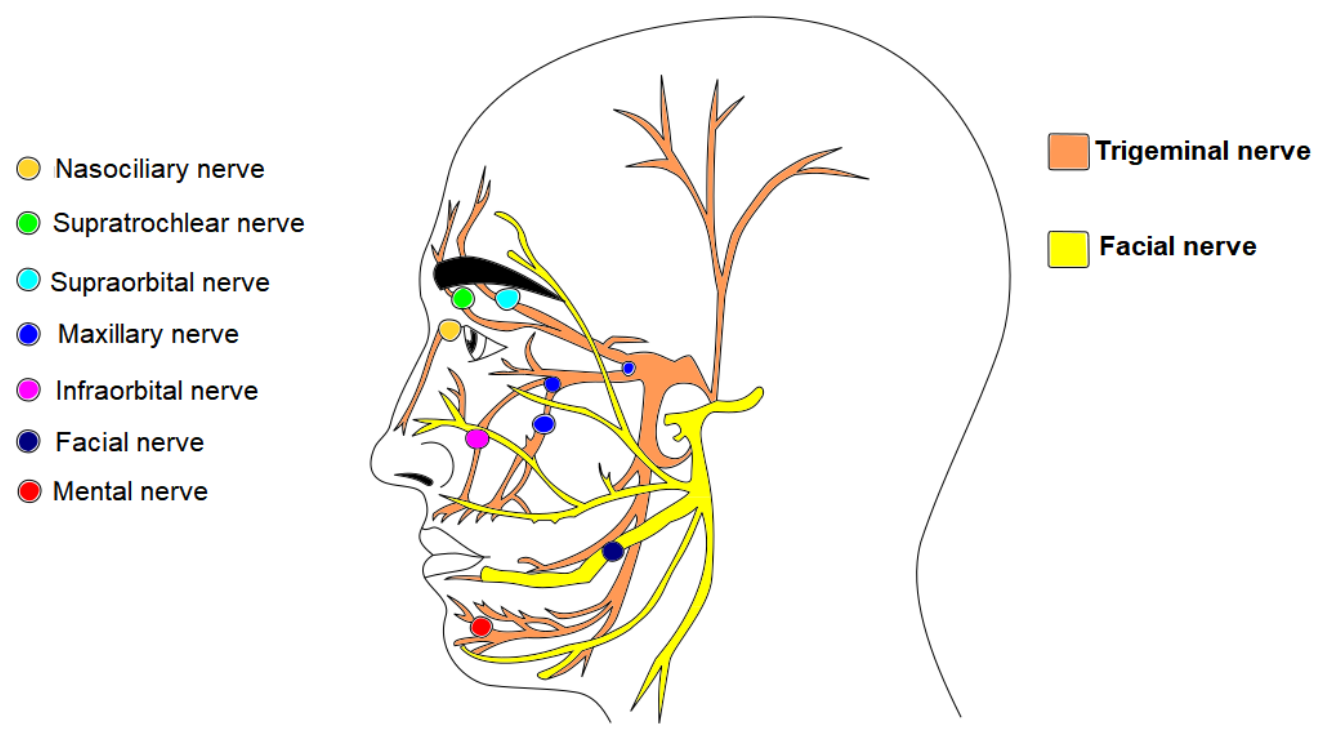

Skin sensitivity points measured with the esthesiometer

(According to the Atlases of Regional Anesthesia Techniques from the Brazilian Anesthesiology Society)

Source: The authors

Figure 2. Regional block points for the measurement of skin sensitivity

After confirming the points, the volunteers had their skin sensitivity threshold measured with the esthesiometer - the central objective of this study. The esthesiometry was performed after a 15-minute break to minimize potential interferences resulting from the stimulation used to confirm the points.

The esthesiometer has standardized monofilaments of various diameters and equal length, differentiated by their colors. Each color, with a distinct grammage, represents a sensitivity threshold ${ }^{22}$. This set of filaments is available in the Semmes-Weinstein manufactured by Sorri ${ }^{\circledR}$ (Figure 3).

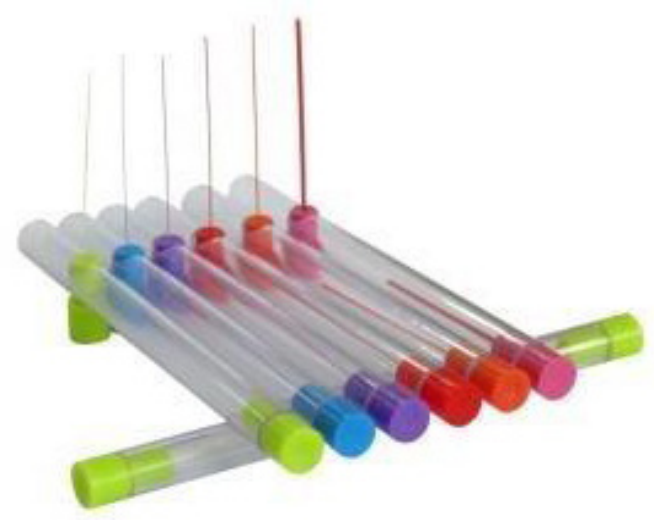

Source: Public domain

Figure 3. Sorri® Semmes-Weinstein Esthesiometer
Before measuring, the researcher conducted the procedure on the back of the volunteer's hand for them to get familiar with the stimulus. Then, the participant was asked to remain seated with their head in the habitual position and eyes closed, to extinguish the visual cue.

To measure skin sensitivity, the filaments were perpendicularly positioned on the person's face and pressed against their skin until it buckled ${ }^{22}$ (Figure 4). The participant was asked to answer "yes" when they felt the touch, even if it were subtle.

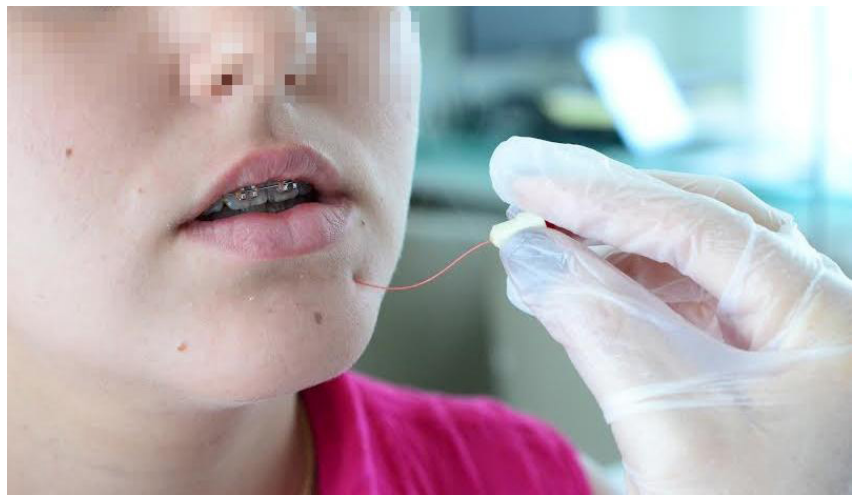

Source: The authors

Figure 4. Use of the esthesiometer in an evaluation 
The evaluation started with the lowest grammage filament (0.05 gf - green) and proceeded with filaments of increasing grammage until the highest one (300.0 gf - pink) (Figure 3), as instructed by the esthesiometer's manual. The first (green $-0.05 \mathrm{gf}$ ) and second filaments (blue $-0.2 \mathrm{gf}$ ), were tested three times. It was considered conclusive to the stimulus if it obtained a positive response in at least one of the attempts. As for the other filaments, they were tested only once, also following the instrument's directions for use.

The responses were recorded in a collection protocol (Figure 5).

\section{INSTRUMENT FOR THE EVALUATION OF SKIN SENSITIVITY WITH AN \\ ESTHESIOMETER}

Name:

Date:

No. :

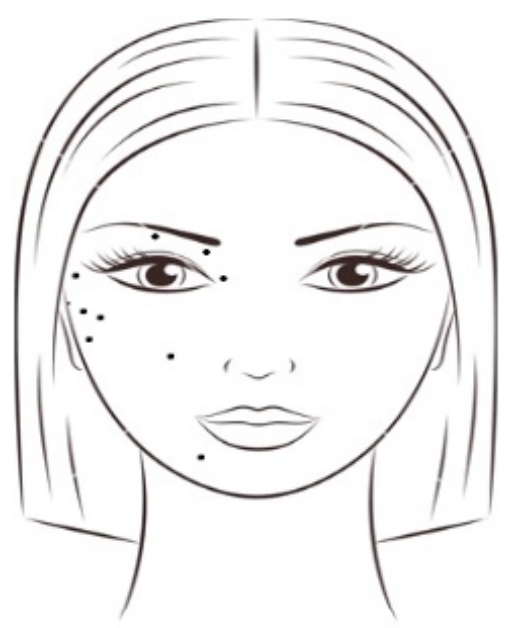

Legend:
1. Supraorbital nerve
2. Supratrochlear
nerve
3. Nasociliary nerve
4, 5, 6 . Maxillary nerve
7. Infraorbital nerve
8.Mental nerve
9. Facial nerve

Check the boxes whose region/filament does not respond to the stimulus

\begin{tabular}{|c|c|c|c|c|c|c|c|c|c|c|c|c|}
\hline \multirow{4}{*}{ Region } & \multicolumn{12}{|c|}{ Monofilaments } \\
\hline & \multirow{2}{*}{\multicolumn{2}{|c|}{$\begin{array}{c}\text { Green } \\
(0.05 \mathrm{gf}) \\
\text { Hemiface }\end{array}$}} & \multirow{2}{*}{\multicolumn{2}{|c|}{$\begin{array}{c}\text { Blue } \\
(0.2 \mathrm{gf}) \\
\text { Hemiface }\end{array}$}} & \multirow{2}{*}{\multicolumn{2}{|c|}{$\begin{array}{c}\text { Violet } \\
(2.0 \mathrm{gf}) \\
\text { Hemiface }\end{array}$}} & \multirow{2}{*}{\multicolumn{2}{|c|}{$\begin{array}{c}\text { Red } \\
(4.0 \mathrm{gf}) \\
\text { Hemiface }\end{array}$}} & \multirow{2}{*}{\multicolumn{2}{|c|}{$\begin{array}{c}\text { Orange } \\
\text { (10.0 gf) } \\
\text { Hemiface }\end{array}$}} & \multirow{2}{*}{\multicolumn{2}{|c|}{$\begin{array}{c}\text { Pink } \\
\text { (300 gf) } \\
\text { Hemiface }\end{array}$}} \\
\hline & & & & & & & & & & & & \\
\hline & $R$ & $\mathrm{~L}$ & $R$ & $\mathrm{~L}$ & $R$ & $\mathrm{~L}$ & $R$ & $\mathrm{~L}$ & $R$ & $\mathrm{~L}$ & $R$ & $\mathrm{~L}$ \\
\hline 1 & & & & & & & & & & & & \\
\hline 2 & & & & & & & & & & & & \\
\hline 3 & & & & & & & & & & & & \\
\hline 4 & & & & & & & & & & & & \\
\hline 5 & & & & & & & & & & & & \\
\hline 6 & & & & & & & & & & & & \\
\hline 7 & & & & & & & & & & & & \\
\hline 8 & & & & & & & & & & & & \\
\hline 9 & & & & & & & & & & & & \\
\hline
\end{tabular}

Figure 5. Response marking sheet and filament table 
The difference in sensitivity was defined in this study as the absence of similar responses between analogous points on both sides of the face - i.e., there was a difference in sensitivity when at the same point on opposite sides the patient responded to filaments of different grammage.

\section{Data analysis procedure}

The data were expressed in percentage and absolute frequencies for the categorical variables, and statistical values (mean, standard deviation, and median) for age. To evaluate the association between two variables, the Pearson chi-square test was used - or, in the variables whose condition for using the chi-square was not verified, the Fisher exact test was used.

The margin of error used in the decisions of the statistical tests was $5 \%$. The data were entered into an Excel spreadsheet, and the statistical calculation was done in the IBM SPSS software, version 23.

\section{RESULTS}

The participants' age ranged from 18 to 73 years, mean of 40.23 years, a standard deviation of 16.13 years, and median 40.00 years. Most (83.3\%) of the participants were females. Regarding age group, the less prevalent $(15.0 \%)$ were those 60 to 73 years old, whereas the percentages of those 18 to 39 years old and 40 to 59 years old were $46.7 \%$ and $38.3 \%$, respectively.

Of the 60 participants, the highest percentage $(41.7 \%)$ was of people with severe DMF, followed by $35.0 \%$ with moderate DMF, and $23.3 \%$ with mild DMF. A difference between analogous points was recorded in $35.0 \%$ - of which, $28.3 \%$ had one to three points with a difference, while the other $6.7 \%$ had four to nine points with a difference.

The association between the presence or not of a difference between analogous points and each of the variables (age group and severity of the TMD) is shown in Table 1. The percentage with a difference between analogous points was higher among those 60 years old or more $(77.8 \%)$, and it increased along with the severity of TMD: $7.1 \%$ among those classified with mild TMD, $33.3 \%$ with moderate TMD, and $52.0 \%$ with severe TMD.

The age group was the only variable with an association. The frequency of one to three different points occurred in five out of the nine subjects 60 years old or more, $30.4 \%$ in the 40 -to-59 age group, and $17.9 \%$ in the 18-to-39 age group. The four to nine points of difference did not occur among those 40 to 59 years old, although it did take place in two people 60 years or more, and in $7.1 \%$ of those 18 to 39 years old (Table 2).

Table 1. Results of the evaluation of differences between analogous points, according to gender, age group, and severity of the temporomandibular disorder

\begin{tabular}{|c|c|c|c|c|c|}
\hline \multirow{3}{*}{ Variable } & \multicolumn{4}{|c|}{ Difference between analogous points } & \multirow{3}{*}{ p-value } \\
\hline & \multicolumn{2}{|c|}{ Yes } & \multicolumn{2}{|c|}{ No } & \\
\hline & $\mathbf{n}$ & $\%$ & $\mathbf{n}$ & $\%$ & \\
\hline Gender & & & & & $p^{(1)}=0.729$ \\
\hline Males & 4 & 40.0 & 6 & 60.0 & \\
\hline Females & 17 & 34.0 & 33 & 66.0 & \\
\hline Age group & & & & & $p^{(1)}=0.013^{*}$ \\
\hline 18 to 39 & 7 & 25.0 & 21 & 75.0 & \\
\hline 40 to 59 & 7 & 30.4 & 16 & 69.6 & \\
\hline 60 or more & 7 & 77.8 & 2 & 22.2 & \\
\hline Temporomandibular disorder & & & & & $\mathrm{p}^{(1)}=0.019^{*}$ \\
\hline Mild & 1 & 7.1 & 13 & 92.9 & \\
\hline Moderate & 7 & 33.3 & 14 & 66.7 & \\
\hline Severe & 13 & 52.0 & 12 & 48.0 & \\
\hline
\end{tabular}

(*) Significant association at 5\%

(1) Fisher's exact test 
Table 2. Results of the evaluation of the number of different points, according to gender, age group, and severity of the temporomandibular disorder

\begin{tabular}{|c|c|c|c|c|c|c|c|}
\hline \multirow{3}{*}{ Variable } & \multicolumn{6}{|c|}{ Number of different points } & \multirow{3}{*}{ p-value } \\
\hline & \multicolumn{2}{|c|}{ None } & \multicolumn{2}{|c|}{ From 1 to 3} & \multicolumn{2}{|c|}{ From 4 to 9} & \\
\hline & $\mathrm{n}$ & $\%$ & $n$ & $\%$ & $\mathbf{N}$ & $\%$ & \\
\hline Gender & & & & & & & $p^{(1)}=0.861$ \\
\hline Males & 6 & 60.0 & 3 & 30.0 & 1 & 10.0 & \\
\hline Females & 33 & 66.0 & 14 & 28.0 & 3 & 6.0 & \\
\hline Age group (years) & & & & & & & $\mathrm{p}^{(1)}=0.013^{\star}$ \\
\hline 18 to 39 & 21 & 75.0 & 5 & 17.9 & 2 & 7.1 & \\
\hline 40 to 59 & 16 & 69.6 & 7 & 30.4 & - & - & \\
\hline 60 or more & 2 & 22.2 & 5 & 55.6 & 2 & 22.2 & \\
\hline Temporomandibular disorder & & & & & & & $p^{(1)}=0.065$ \\
\hline Mild & 13 & 92.9 & 1 & 7.1 & - & - & \\
\hline Moderate & 14 & 66.7 & 6 & 28.6 & 1 & 4.8 & \\
\hline Severe & 12 & 48.0 & 10 & 40.0 & 3 & 12.0 & \\
\hline
\end{tabular}

${ }^{*}$ ) Significant association at $5 \%$

(1) Fisher's exact test

\section{DISCUSSION}

When this investigation's sample characteristics are observed, the findings coincide with the profile of patients with facial chronic pain proposed in some studies that indicated a higher prevalence of pain in female patients ${ }^{23,24}$ over 30 years old ${ }^{25}$. The mean age in this study was 40 years, nearing the findings of another investigation whose mean was approximately 38 years ${ }^{26}$.

An epidemiologic study points to an association between females and TMD, justifying that osseous and psychosocial pathologies affect more women than men. It also indicates that the prevalence of temporomandibular disorder symptoms is higher in reproductive-age females due to estrogen, which regulates the growth and development of bones ${ }^{27}$.

A previously cited study justifies the higher prevalence of women with TMD by the different physiological conditions between the genders, such as the greater ligament laxity (which hinders the stabilization of the TMJ) and hormonal issues (which make women more prone to suffering physical and psychological tensions) $)^{25}$.

The increase in the percentage of difference in sensitivity between analogous points corresponding to increase in age was similar to that found in a study that used the same instrument (Semmes-Weinstein monofilaments) to evaluate skin sensitivity in other parts of the body ${ }^{28}$. That investigation ${ }^{28}$ and other studies ${ }^{29,30}$ report a decreased skin sensitivity in older adults. The justification for this diminished response lies in the classic characteristics of human aging and changes in the nervous system, with loss of myelinated and unmyelinated fibers and slowed nervous conduction ${ }^{31}$.

In another study ${ }^{32}$ evaluating plantar sensitivity with this same instrument, the responses decreased in relation to the participants' age. The decrease in skin mechanoreceptors and neural excitability, inherent to aging, can determine a negative relationship between skin sensitivity and an increase in age. In the present paper, an association was likewise verified between the number of analogous points on the face with a difference in sensitivity and the increase in age.

The occurrence in this study of a higher percentage of individuals with differences in sensitivity between analogous points of the face can be justified by the fact that clinical changes, such as the increase in skin sensitivity and hyperalgesia, are observed in patients with general orofacial pains ${ }^{33}$.

In yet another study ${ }^{34}$ that evaluated plantar sensitivity, changed sensitivity was verified in subjects with fibromyalgia. The authors hypothesize that there was a pain processing hyperstimulation, modulated in the central nervous system, due to the nociceptive sensitivity variations in the skeletal muscle and, consequently, these patients' exacerbated responses. However, what happened was the decrease in response to the stimulus with the esthesiometer. In this regard, the presence of pain seems to somehow change the response to skin stimulus. 
A study ${ }^{35}$ relating headache and TMD to the increase in pericranial sensitivity justifies that the relationship takes place through a physiopathological mechanism of the trigeminal nerve, which is the one responsible for orofacial sensitivity. Nonetheless, it should be highlighted that the data presented in this investigation did not take complaints of headache into account, despite being a common symptom in patients with TMD.

No association was perceived between gender and difference in sensitivity in analogous points of the face. A piece of research on the sensitivity of lesioned hands of male and female soccer goalkeepers did not find changes - both the men and the women obtained normal values in the esthesiometry ${ }^{36}$. It is suggested that an investigation be conducted to relate these two variables.

On the other hand, an evaluation of thermal perception in men and women showed that there are differences in the neural mechanisms in response to a thermal stimulus. It also pointed out that there are greater differences between the regions of the women's body than of men's, either for cold or heat ${ }^{37}$. In the present study, no thermal stimuli were used; however, the skin receptors that respond to hot, cold, and soft touch/deep pressure stimuli are the same ${ }^{2}$.

As previously stated, women are more prone to suffering from psychological tensions ${ }^{25}$. When this issue is discussed, it is known that anxiety and depression can induce or aggravate TMD symptoms ${ }^{38,39}$. Considering that sensitivity change ${ }^{33}$ is a common symptom of this disorder, it can be suggested that women present this difference more often than men.

A minimum amount of studies approaching temporomandibular disorder and skin sensitivity was found. Hence, the present research is in want of a more detailed investigation.

Self-medication, which was not controlled in this study, can be a limitation. Having undergone dental treatment for TMD was among the exclusion criteria. However, taking anti-inflammatories, muscle relaxants, antidepressants, and other drugs commonly prescribed independently to patients with pain was not analyzed.

It is suggested that further studies be conducted, evaluating other variables involved in the perception of skin sensitivity thresholds in patients with temporomandibular disorder.

\section{CONCLUSION}

This investigation led to the conclusion that it is possible to find sensitivity changes in people with complaints of TMD, especially in the most severe cases.

In this sample, it was also observed that sensitivity was changed in adults over 60 years old with TMD. Moreover, an association was found between the age group and the number of analogous points of the face with a difference in sensitivity.

\section{ACKNOWLEDGMENT}

Gratitude is extended to the Research and Postgraduation Dean for the opportunity to carry out this research.

Gratitude is also extended to the Orofacial Pain Control Center of the Faculdade de Odontologia de Pernambuco and the Department of Speech-LanguageHearing Sciences of the Universidade Federal de Pernambuco for their consent and collaboration.

\section{REFERENCES}

1. Douglas CR. Sensibilidade proprioceptiva estomatognática. In: Douglas CR. Tratado de fisiologia aplicada às ciências médicas. 4a ed. Rio de Janeiro: Guanabara Koogan; 2006. p. 829-37.

2. Dapper MB. Reprodutibilidade de três testes para avaliação da sensibilidade da mão em indivíduos assintomáticos [Dissertação]. Porto Alegre (RS): Pontifícia Universidade Católica do Rio Grande do Sul; 2007.

3. Romeiro V. Exame da sensibilidade. In: Romeiro V. Semiologia Médica. Rio de Janeiro: Guanabara Koogan; 1968. p. 712-20.

4. Nunes ALB, Portella MQ, Feres MAL. Ortodontia: fator etiológico ou tratamento de disfunção temporomandibular? Ortodontia. 2016;48(2):145-50.

5. Santos LHG. Avaliação funcional da disfunção temporomandibular após bioestimulação associado à cinesioterapia. Fisioterapia Brasil. 2016;13(4):264-71.

6. Poluha RL, Silva RS, Conti PCR, Mitrirattanakul $S$, Merril R. Índices de ansiedade, depressão e incapacidade em pacientes com dor miofascial com e sem o diagnóstico adicional de enxaqueca. Rev. Dor. 2017;18(3):189-93.

7. Auvenshine RC. Temporomandibular disorders: associated features. Dent Clin North Am. 2007;51(1):105-27. 
8. Mello MVFM. Disfunção temporomandibular e fatores associados em trabalhadores [Dissertação]. Salvador (BA): Universidade Federal da Bahia; 2014.

9. Sydney PBH, Conti PCR. Diretrizes para avaliação somatossensorial em pacientes portadores de disfunção temporomandibular e dor orofacial. Rev Dor. 2011;12(4):349-53

10. Motta LJ, Bussadori SK, Godoy CLH, BiazottoGonzales DA, Martins MD, Silva RS. Disfunção temporomandibular segundo o nível de ansiedade em adolescentes. Psicologia: Teoria e Pesquisa. 2015;31(3):389-95.

11. Baltazar CF. O impacto das disfunções temporomandibulares crónicas na qualidade de vida [Dissertação]. Porto (Portugal): Universidade Fernando Pessoa - Faculdade das Ciências da Saúde; 2017.

12. Fehrenbach J, da Silva BSG, Pradebon Brondani LP. A associação da disfunção temporomandibular à dor orofacial e cefaleia. Journal of Oral Investigations. 2018;7(2):69-78.

13. Gregório AO, Cavalheiro R, Tirelli R, Fréz AR, Ruaro $M B$, Ruaro JA. Influência do tempo de aplicação da crioterapia na sensibilidade cutânea. Rev. Dor. 2014;15(1):9-12.

14. Coelho VAFP, Nahas FX, Bauleo ABF, Juliano Y, Ferreira LM. Avaliação da eficácia do uso dos monofilamentos de Semmes-Weinstein para avaliação da sensibilidade abdominal. Rev. Bras. Cir. Plást. 2014;29(3):410-5.

15. Graziani AF, Garcia CFS, Berretin-Felix G, Genaro KF. Orthognathic surgery effect of orofacial sensitivity in individuals with cleft lip and palate. Rev. CEFAC. 2016;18(3):581-8.

16. Dias CS, Alfieri FM, Battistella LR. Utilização de monofilamentos para avaliação sensorial em pacientes com sequela de Acidente Vascular Encefálico (AVE) - uma revisão sistemática. Rev Bras Neurol. 2019;55(3):22-8.

17. Fonseca DM, Bonfante G, Valle AL, Freitas SFT. Diagnóstico pela anamnese da disfunção craniomandibular. RGO. 1994;42(1):23-8.

18. Motta TS, Gambaro RC, Santos FC. Mensuração da dor em idosos: avaliação das propriedades psicométricas da versão em português do Geriatric Pain Measure. Rev. Dor. 2015;16(2):136-41.

19. Sociedade Brasileira de Anestesiologia. Atlas de técnicas de bloqueios regionais. Rev. Bras. Anestesiologia. 1995;18(8):7-22.
20. Santos Júnior O. Análise de variações anatômicas neurovasculares da maxila por meio da tomografia computadorizada por feixe cônico [Dissertação]. Ponta Grossa (PR): Universidade Estadual de Ponta Grossa; 2018.

21. Colossi MJG. Revisão sistemática das variações anatômicas do nervo facial [Dissertação]. Salvador (BA): Universidade Federal da Bahia; 2016.

22. Studart-Pereira LM, Benevides SD. A fonoaudiologia e a cirurgia ortognática. In: Silva HJ, Tessitore A, Motta AR, Cunha DA, Berretin-Felix G, Marchesan IQ (orgs). Tratado de motricidade orofacial. 10 ed. São José dos Campos: Pulso editorial; 2019. p. 611-30.

23. Freitas WMTM, Santos AKF, Saliba EM, Silva EA. Avaliação da qualidade de vida e da dor em indivíduos com disfunção temporomandibular. Revista Pesquisa em Fisioterapia. 2015;5(3):210-7.

24. Ferreira CLP, Silva MAMR, Felicio CM. Signs and symptoms of temporomandibular disorders in women and men. CoDAS. 2016;28(1):17-21.

25. Dantas AMX, Santos EJL, Vilela RM, Lucena LBS. Perfil epidemiológico de pacientes atendidos em um Serviço de Controle da Dor Orofacial. Rev Odontol UNESP. 2015;44(6):313-9.

26. Tacon KCB, Gomes FS, Souza SG, Tacon FSA, Amaral WN. Análise do perfil clínico-epidemiológico dos pacientes com disfunção temporomandibular atendidos em uma clínica escola em Anápolis-GO. Revista Educação em Saúde. 2017;5(2):1-5.

27. Bastos JM, Gonçalves LS, Isaías PHC, Silva RADA, Bastos PL, Figueiredo VMG. Disfunção temporomandibular: uma revisão de literatura sobre epidemiologia, sinais e sintomas e exame clínico. Revista da Saúde e Biotecnologia. 2017;1(1):66-77.

28. Santos AD. Reprodutibilidade inter e intra avaliador e a validade concorrente do teste de sensibilidade tátil da planta dos pés por meio dos monofilamentos de semmes - weinstein em pessoas idosas [Dissertação]. São Paulo (SP): Universidade Cidade de São Paulo; 2015.

29. Dantas ROL, Leorne GSM, Wagner LMS, Gouveia GPM, Gouveira SSV. Análise do equilíbrio e da sensibilidade plantar como preditores de quedas em idosos de Morrinhos/CE. Fisioter Bras. 2018;19(5):641-50.

30. Moura SRB, Marques Junior MASS, Oliveira TA, Nascimento LDS, Mesquita GV, Brito JNPO. Fatores associados à queda de idosos que podem 
resultar em fratura de fêmur. Rev Enferm UFPE. 2016;10(2):720-6.

31. Alfieri FM, Vieira CF, Vargas e Silva NCO. Controle postural e sensibilidade plantar em jovens e idosos. Revista Saúde. 2019;45(2):1-9.

32. Menezes GS, Faria MC, Santos DB, Barros CF, Oliveira FB. Correlação entre a sensibilidade cutânea plantar e a idade: um estudo transversal. $R$ Bras Ci e Mov. 2019;27(2):28-36.

33. Silva JC, Saraiva SRGL, Oliveira Júnior RG, Almeira RGS. Modelos experimentais para avaliação da atividade antinociceptiva de produtos naturais: uma revisão. Rev Bras Farm. 2013;94(1):18-23.

34. Camargos JCV, Vieira LA, Moraes GS, Rinaldi NM. Influência da fibromialgia nos ajustes posturais, na sensibilidade cutânea e na amplitude de movimento de membros inferiores. BJMB. 2018;12(1):1-11.

35. Magazoni VS, Cardoso Filho GM, Makhoul KDL, Guimarães EA, Natal MG. Avaliação das disfunções temporomandibulares e função mandibular em acadêmicos com cefaleia tensional do tipo crônica. E-RAC. 2016;6(1):1-10.

36. Vianna DL, Ciochetti El, Gomes AL, Fernandes SM. Estudo de lesões nas mãos de goleiros do sexo masculino e feminino e o desempenho da força de preensão manual e sensibilidade cutânea. RPF. 2016;6(3):208-16.

37. Araújo SR. Avaliação da percepção térmica de homens e mulheres durante o exercício autorregulado [Dissertação]. Viçosa (MG): Universidade Federal de Viçosa; 2018.

38. Braga AC, Souza FLD. Transtornos psicológicos associados à disfunção temporomandibular. Psicodebate. 2016;2(1):100-20.

39. Zavanelli AC, Alves Rezende MCR, Santos-Neto OM, Fajardo RS. Integração da Psicologia e Odontologia na DTM: revisão sistematizada. Arch Health Invest. 2017;6(11):530-4. 